\title{
PREPARATION AND PURIFICATION OF RECOMBINANT OUTER SURFACE PROTEIN A (rOspA) OF BORRELIA BURGDORFERI SENSU STRICTO AND BORRELIA AFZELII
}

\author{
Jana Bělákováa, Michal Křupka ${ }^{a}$, Martina Šebestováa, Jana Tuháčkováb, Vladimír Vrzal ${ }^{b}$, \\ Milan Raška ${ }^{a}$, Evžen Weigl ${ }^{\mathrm{a}}$
}

\author{
a Department of Immunology, Faculty of Medicine, Palacký University, Olomouc, Czech Republic \\ ${ }^{b}$ Bioveta, a.s., Komenského 212, 68323 Ivanovice na Hané, Czech Republic \\ e-mail:janabelakova@seznam.cz
}

Received: September 16, 2005; Accepted (with revisions): November 4, 2005

Key words: Outer surface protein A (OspA)/Borrelia burgdorferi/Ni-NTA Agarose/Lyme borreliosis

The recombinant Outer surface protein A (rOspA) from Borrelia burgdorferi is a possible immunogen for protection of infected humans and animals against development of Lyme borreliosis (Lyme disease), a chronic tick-borne disease characterised by diverse dermatologic, neurologic, rheumatic, and cardiac manifestations. For several years, research and development have been directed towards a vaccine for the prevention of this debilitating disease. Numerous animal studies demonstrate that pre-existing antibodies against the outer surface proteins of $B$. burgdorferi can prevent infection and disease caused by this organism. In this communication, using recombinant DNA technology, genes from B. burgdorferi sensu stricto and B. afzelii were inserted into E. coli-expression vectors and the rOspA were produced. Our aim was to obtain rOspA protein in a purity and quantity desirable for immunization of experimental animals. rOspA is currently the most developed, molecularly-defined vaccine candidate for the prevention of Lyme borreliosis.

\section{INTRODUCTION}

Lyme borreliosis is a multisystem inflammatory disease caused by Borrelia burgdorferi a gram-negative spirochete ${ }^{1}$, transmitted by the bite of infected ixodes ticks. B. burgdorferi sensu lato has been divided in to 11 genospecies. Of these, three species are recognized as pathogenic for humans: all of which are present in Europe: $B$. burgdorferi sensu stricto, the only species causing Lyme borreliosis in the United States; B. afzelii; and $B$. garinii. These spirochetes alternate in nature between warm-blooded hosts (mammals) and poikilothermic vectors. The tick Ixodes ricinus is the main vector of these pathogens ${ }^{2}$. In the vector, the spirochetes replicate during the feeding process ${ }^{3}$, migrate through the gut wall, and invade various tissues, including the salivary glands, from where they are transmitted to the host blood via saliva ${ }^{4}$. OspA is abundantly expressed in unfed ticks, probably mediating adherence to midgut cells ${ }^{5}$ and thus enabling borreliae to survive in the vector for prolonged periods without tick feeding. B. burgdorferi expresses OspA but not $\mathrm{OspC}$ when residing in the midgut of unfed ticks. However, when the tick starts feeding on mammals, OspC synthesis is induced and OspA is repressed ${ }^{6}$. The switch is in part due to the change in temperature ${ }^{7}$.

Outer surface protein A (OspA) (molecular weight $31 \mathrm{kDa}$ ), a species-specific surface lipoprotein that presents together with the flagellin approximately one third of the total spirochete protein. The crystal structure of OspA consists of a single-layer beta-sheet connecting $\mathrm{N}$-terminal and C-terminal globular domains. The central beta-sheet consists largely of polar amino acids that are solvent-exposed on both faces; this seems to be unique among protein structures ${ }^{8}$. More than 100 other proteins have also been identified in the spirochete's genome, including OspB, OspC, OspD, OspE, and $\mathrm{OspF}\left(\right.$ ref. $\left.^{9}\right)$.

The OspA protein has been used as most promising candidate for vaccine against infection with $B$. burgdorferi. The ospA gene of B. burgdorferi encodes an outer membrane protein which is a major antigen of the Lyme disease agent. OspA elicits immunity against $B$. burgdorferi infection and is being used as a human vaccine ${ }^{10}$. OspA antibody blocks spirochete transmission to the vertebrate host by binding to $B$. burgdorferi within the gut of engorging ixodes ticks ${ }^{11}$.

Active immunization studies with OspA immunogens shown high-level of protection in mice. Humoral immunity is sufficient for protection. Although binding to an antigenic determinant (conformational epitope) located within the carboxyl end of OspA appears to be important for protection, the mechanism of protection conferred by antibodies has not been established. A principal drawback of the vaccine is the heterogeneity of OspA protein among particular B. burgdorferi isolates ${ }^{12}$.

At present, two human Lyme borreliosis vaccines use recombinant OspA (rOspA) from B. burgdorferi sensu 
a)

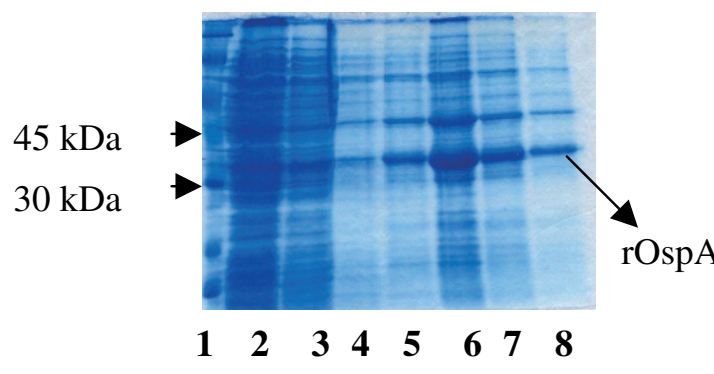

b)

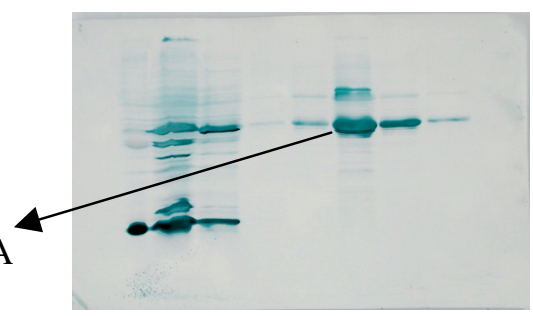

$\begin{array}{llllllll}1 & 2 & 3 & 4 & 5 & 6 & 7 & 8\end{array}$

Fig. 1. a) SDS-PAGE of rOspA proteins from B. burgdorferi sensu stricto stained with Coomassie Blue and b) Western immunoblot developed with Penta-His HRP antibodies. Lane 1, High-Range Rainbow Molecular Weight Markers (Amersham Biosciences); Lane 2, flow-through fraction; Lanes 3 and 4, wash fractions; Lanes 5, 6, 7 and 8, elution fractions.

a)

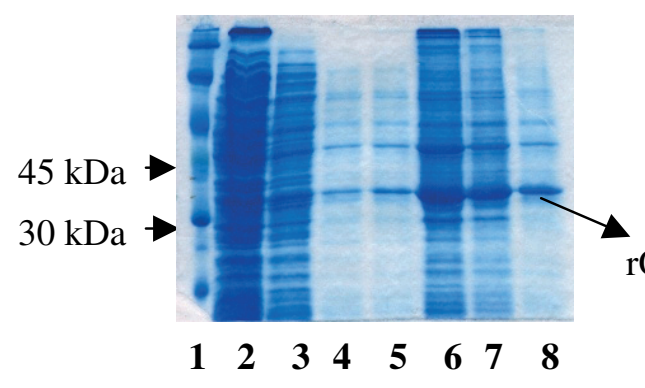

b)

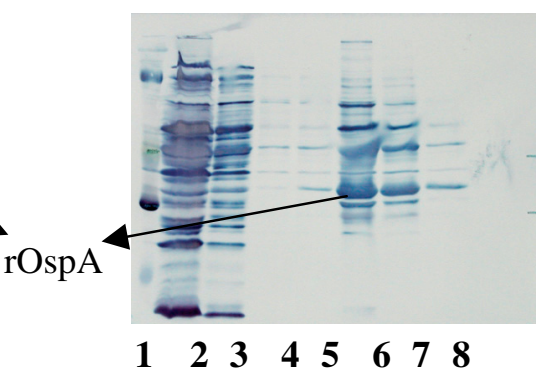

Fig. 2. a) SDS-PAGE of rOspA proteins from B. afzelii stained with Coomassie Blue and b) Western immunoblot developed with Penta-His HRP antibodies. Lane 1, High-Range Rainbow Molecular Weight Markers (Amersham Biosciences); Lane 2, flow-through fraction; Lanes 3 and 4, wash fractions; Lanes 5, 6, 7 and 8, elution fractions.

stricto. LYMErix, produced by SmithKline Beecham, and licensed for use in Canada, contains $30 \mu \mathrm{g}$ of purified lipidated-rOspA protein combined with $0.5 \mathrm{mg}$ of aluminium adjuvant ${ }^{13}$. The vaccine stimulates host immune system to produce OspA - specific antibodies. Studies suggest that when a tick bites a vaccinee, the antibodies enter and contribute to killing the bacteria in the tick. A second vaccine, ImuLyme, produced by Pasteur Merieux Connaught, contains $30 \mu \mathrm{g}$ of purified lipidated-rOspA protein without adjuvant. The ImuLyme vaccine induces killing of the spirochetes within the tick before it can enter the human bloodstream ${ }^{14}$.

\section{MATERIALS AND METHODS}

Plasmid DNA was isolated from B. burgdorferi sensu stricto and $B$. afzelii. The DNA was used as a template for the PCR amplification of the OspA gene which was after purification (QIAEX II Gel Extraction kit, Qiagen) cloned into expression vector pDEST ${ }^{\mathrm{TM}} 17$ (Invitrogen) using Gateway ${ }^{\mathrm{TM}}$ Technology (GT). His-tag-fused OspA protein was expressed in expression competent $E$. coli BL21 Star (DE3) (Invitrogen). BL21 Star (DE3) were grown for $12 \mathrm{~h}$ at $37^{\circ} \mathrm{C}$ in 2 liters of the LB medium un- til they reached mid-log $\left(\mathrm{OD}_{600}=0.6\right)$. IPTG (SERVA) was added at a final concentration of $0.1 \mathrm{mM}$, and the culture was incubated for another $4 \mathrm{~h}$. Cells were collected by centrifugation (10.000 RPMI, $\left.10 \mathrm{~min} ., 4^{\circ} \mathrm{C}\right)$, resuspended in lysis buffer (lysis buffer: $50 \mathrm{mM} \mathrm{NaH} \mathrm{PO}_{4}$. $\mathrm{H}_{2} \mathrm{O}, 300 \mathrm{mM} \mathrm{NaCl}, 10 \mathrm{mM}$ imidazol, $\mathrm{pH}=8$ ) containing lysozyme $(0.5 \mathrm{mg} / \mathrm{ml})$ and incubated for $1 \mathrm{~h}$ at $4{ }^{\circ} \mathrm{C}$. After $10 \times 10 \mathrm{~s}$ ultrasonic pulsions homogenisation lysate was centrifuged (10.000 RPMI, 10 min., $4{ }^{\circ} \mathrm{C}$ ) and $4 \mathrm{ml}$ of the cleared supernatant was mixed with $1 \mathrm{ml}$ of the $50 \%$ Ni-NTA slurry (Qiagen) for $1 \mathrm{~h}$ at $4{ }^{\circ} \mathrm{C}$. The supernatant - Ni-NTA mixture was loaded into a gravity column (Sigma) and washed twice with $4 \mathrm{ml}$ washing buffer (washing buffer: $50 \mathrm{mM} \mathrm{NaH} \mathrm{PO}_{4} \cdot \mathrm{H}_{2} \mathrm{O}, 300 \mathrm{mM} \mathrm{NaCl}$, $30 \mathrm{mM}$ imidazol, $\mathrm{pH}=8)$. Protein was eluted with $4 \times$ $0.5 \mathrm{ml}$ of elution buffer (elution buffer: $50 \mathrm{mM} \mathrm{NaH} \mathrm{PO}_{4}$. $\mathrm{H}_{2} \mathrm{O}, 300 \mathrm{mM} \mathrm{NaCl}, 250 \mathrm{mM}$ imidazol, $\mathrm{pH}=8$ ). All buffers contained $5 \mathrm{mM} \beta$ - mercaptoethanol, 0.5 mM PMSF, $2 \mu \mathrm{g} / \mathrm{ml}$ Leupeptin and $0.1 \mu \mathrm{g} / \mathrm{ml}$ Aprotinin. The fractions were analyzed using $12 \%$ SDS-PAGE and Western immunoblot. Total protein was stained on gel with Coomassie brilliant blue. Protein blotted on PVDF membranes were incubated with Penta-His HRP antibodies (Qiagen) and detected by a color reaction using TMB Membrane Substrate (Amresco). 

and Borrelia afzelii

Fractions with maximum concentration of rOspA were dialyzed against $200 \mathrm{mM} \mathrm{NaCl}$ at $4{ }^{\circ} \mathrm{C}$ overnight.

\section{RESULTS}

The rOspA proteins from B. burgdorferi sensu stricto and $B$. afzelii present $80 \%$ of total protein in elution fractions and they were specifically recognized with Penta-His antibodies (Fig. 1, Fig. 2). The concentration of rOspA from $B$. burgdorferi sensu stricto $(0.4 \mathrm{mg} / \mathrm{ml})$ and $B$. afzelii $(0.3 \mathrm{mg} / \mathrm{ml})$ were measured using a densitometer.

Overdialyzed fractions with maximum concentration of rOspA were tested using polyclonal anti-OspA-IgG antibodies (by Bioveta, a.s.). The rOspA proteins reacted with this antibodies (data is not shown).

\section{CONCLUSION}

Purification of recombinant OspA from B. burgdorferi sensu stricto and $B$. afzelii by nickel-nitrilotriacetic acid (Ni-NTA) metal-affinity chromatography under native conditions is highly effective. Proof of the 'principle' that rOspA is a protective antigen (as a possible immunogen to protect against Lyme borreliosis) will be confirmed by active immunization experiments in mice.

\section{ACKNOWLEDGEMENT}

This work was supported by grant of Ministry of Industry and Business (FD-K3/100).

\section{REFERENCES}

1. Swellengrebel 1907. In.: Bergey's manual of determinative Bacteriology, 8th ed., 1974, Editor: Buchanan, R.E., Gibbons, N.E., Publisher: The Williams \& Wilkins Co., Baltimore.

2. Hu LT, Klempner MS. (1997) Host-pathogen interactions in the immunopathogenesis of Lyme disease. J Clin Immunol. 17, 354-65.

3. Pechova J, Stepanova G, Kovar L, Kopecky J. (2002) Tick salivary gland extract-activated transmission of Borrelia afzelii spirochaetes. Folia Parasitol. 49, 153-9.

4. Schwan TG, Rosa PA. (1995) Temperature-related differential expression of antigens in the Lyme disease spirochete, Borrelia burgdorferi. Infect Immun. 63, 4535-9.

5. Fingerle V, Hauser U, Liegl G, Petko B, Preac-Mursic V, Wilske B. (1995) Expression of outer surface proteins A and C of Borrelia burgdorferi in Ixodes ricinus. Clin Microbiol. 33, 1867-9.

6. Obonyo M, Munderloh UG, Fingerle V, Wilske B, Kurtti TJ. (1999) Borrelia burgdorferi in tick cell culture modulates expression of outer surface proteins $\mathrm{A}$ and $\mathrm{C}$ in response to temperature. J Clin Microbiol. 37, 2137-41.

7. Schwan TG. (2003) Temporal regulation of outer surface proteins of the Lyme-disease spirochaete Borrelia burgdorferi. Biochem Soc Trans. 31, 108-12.

8. Li H, Dunn JJ, Luft BJ, Lawson CL. (1997) Crystal structure of Lyme disease antigen outer surface protein A complexed with an Fab. Proc. Natl Sci USA 94, 3584-9.

9. Kumaran D, Eswaramoorthy S, Luft BJ, Koide S, Dunn JJ, Lawson CL, Swaminathan S. (2001) Links Crystal structure of outer surface protein $\mathrm{C}(\mathrm{OspC})$ from the Lyme disease spirochete, Borrelia burgdorferi. EMBO J. 20, 971-8.

10. de Silva AM, Telford SR, Bruner LR, Berthold SW, Fikrig E. (1996) Borrelia burgdorferi is an arthropod-specific transmission blocking Lyme disease vaccine. J.Exp. Med. 183, 271-5.

11. Pal U, de Silva AM, Montgomery RR, Fish D, Anguita J, Anderson JF, Lobet Y, Fikrig E. (2000) Attachment of Borrelia burgdorferi within Ixodes scapularis mediated by outer surface protein A. J Clin Invest 106, 561-569.

12. Sigal LH, Zahradnik JM, Lavin P, et al. (1998) A vaccine consisting of recombinant Borrelia burgdorferi outer-surface protein A to prevent Lyme disease. Recombinant Outer-Surface Protein A Lyme Disease Vaccine Study Consortium. N Engl J Med 339, 216-22.

13. Steere AC, Sikand VK, Meurice F, Parenti DL, Fikrig E, Schoen RT, Nowakowski J, Schmid CH, Laukamp S, Buscarino C, Krause DS. (1998) Vaccination against Lyme disease with recombinant Borrelia burgdorferi outer-surface lipoprotein A with adjuvant. N Eng J Med 339, 209-15.

14. Meltzer MI, Dennis DT, Orloski KA. (1999) The cost effectiveness of vaccinating against Lyme disease. Emerg Infect Dis 5, 321-8. 